\title{
PREVALENCIA DE BACTERIAS PATÓGENAS DE MASTITIS BOVINA EN LECHE DE TANQUE DE FRÍO Y EVALUACIÓN DE MEDIOS DE CULTIVO PARA EL RECUENTO Y LA IDENTIFICACIÓN DE STAPHYLOCOCCUS AUREUS*
}

\author{
Neder, V. e. ${ }^{1} ;$ Signorini, M. L. ${ }^{1,3} ;$ Cuatrin, A. ${ }^{1}$; \\ GIANRE, V. ${ }^{1} ; \&$ CALVINHO, L. F. ${ }^{1,2}$
}

\begin{abstract}
RESUMEN
El objetivo del presente estudio fue estimar la prevalencia de bacterias patógenas de mastitis en muestras de leche de tanque en tambos ubicados en la cuenca lechera central Argentina. Además, se evaluó el desempeño de tres medios de cultivo, dos estándar (Baird Parker y agar sangre) y uno comercial (Compact Dry "Nissui"), para realizar el recuento, aislamiento e identificación de Staphylococcus aureus. Entre las muestras con aislamiento de patógenos mayores, la prevalencia de $S$. aureus, Streptococcus agalactiae, Streptococcus uberis y Streptococcus dysgalactiae fue del 50\%, $5,45 \%, 31.82 \%$ y $12.72 \%$ respectivamente. Ninguna muestra fue positiva para Mycoplasma spp. Al comparar los medios para aislamiento de $\mathrm{S}$. aureus se observó una concordancia moderada a baja entre Baird Parker (BP) y Agar Sangre (AS), mayor que la observada entre Baird Parker y Compact Dry "Nissui" (CSA). Al comparar el porcentaje de recuperación, ninguna de las dos técnicas AS y CSA difirió de BP la cual fue intermedia a las otras dos, obteniéndose recuentos más bajos en AS que en CSA. Estos resultados evidencian que aún persisten elevadas prevalencias de los principales agentes patógenos de mastitis y su control es importante para mejorar la calidad microbiológica de la leche cruda. Los tres medios ensayados fueron adecuados para la detección de S. aureus en leche de tanque.

Palabras claves: Leche cruda, mastitis, medios de cultivos, Staphylococcus aureus.
\end{abstract}

1.- Estación Experimental Agropecuaria Rafaela, Instituto Nacional de Tecnología Agropecuaria, Ruta $34 \mathrm{Km}$ 227. (2300) Rafaela, provincia de Santa Fe. Email: neder.veronica@inta.gob.ar

2.- Facultad de Ciencias Veterinarias, Universidad Nacional del Litoral. Kreder 2805. Esperanza, provincia de Santa Fe.

3.- Consejo Nacional de Investigaciones Científicas y Técnicas

*Trabajo financiado con fondos de la Asociación Cooperadora de INTA Rafaela

Manuscrito recibido el 27 de marzo de 2014 y aceptado para su publicación el 16 de junio de 2014. 


\section{SUMMARY}

\section{Prevalence of bovine mastitis pathogens in bulk tank milk and evaluation of culture media performance for detection and enumeration of Staphylococcus aureus.}

The objective of this study was to determine the prevalence of major mastitis pathogens in bulk tank milk from dairy herds located in the central dairy area of Argentina. In addition, performance of three culture media, two standard (Baird Parker and blood agar) and one commercial (Dry Compact "Nissui") for Staphylococcus aureus detection and enumeration was evaluated. Prevalence of $S$. aureus, Streptococcus agalactiae, Streptococcus uberis and Streptococcus dysgalactiae was 50\%, $5.45 \%, 31.82$ and 12.72, respectively, while Mycoplasma spp. was not detected. Regarding culture media performance, accordance between Baird Parker and blood agar was moderate to low, although higher than the one observed between Baird Parker and Compact Dry "Nissui". Colony recovery percent on blood agar or Compact Dry "Nissui" did not differ from Baird Parker, being higher on Compact Dry "Nissui" and lower on blood agar. These results stress the need to control major mastitis contagious pathogens in the central dairy area. All culture media evaluated were found suitable for detection and enumeration of S. aureus in bulk tank milk.

Key word: bulk tank milk, bovine mastitis, culture media, Staphylococcus aureus.

\section{INTRODUCCIÓN}

La mastitis bovina es la enfermedad del ganado lechero que mayores pérdidas económicas causa al productor y a la industria procesadora, ya que provoca disminución de la secreción láctea y deterioro de la calidad de la leche (Booth, 1981). Esta enfermedad sigue siendo una de las principales limitantes de la producción lechera en Argentina. Desde fines de la década del 90 hasta mitad de la primera década de 2000 se observaron importantes progresos en el control de la enfermedad, evidenciados por descenso de los recuentos de células somáticas (RCS) en leche de tanque, con valores de 300.000 células/ml en octubre de $2004(\mathrm{n}=6.794$ tambos) (SAGPYA, 2005). Sin embargo, en los últimos años no se han advertido mayores progresos, ya que de febrero de 2011 al mismo mes de 2012 el promedio de valores de RCS fue 382.800 cél/ml (MAGYP, 2012), con incrementos marcados en los recuentos durante el verano.
En Argentina no existen datos actualizados acerca de la prevalencia de patógenos causantes de mastitis bovina. Estudios realizados en las décadas del 80 y 90 en distintas cuencas lecheras a partir de muestras de leche compuesta o de cuartos mamarios obtenidas de mastitis clínicas y subclínicas, mostraban fundamentalmente un predominio de patógenos contagiosos como Staphylococcus aureus y Streptococcus agalactiae, así como distintas especies del género Streptococcus, hallándose porcentajes relativamente menores de organismos coliformes (Calvinho y Tirante, 2005; Dieser et al., 2014).

Estos estudios utilizaron métodos para el cultivo de los patógenos clásicos de mastitis bovina, los cuales no permiten el crecimiento de Mycoplasma. Este organismo es un patógeno contagioso aislado frecuentemente de infecciones intramamarias (IIM) bovinas (González \& Wilson, 2003). Si bien el aislamiento de Mycoplasma bovis fue informado por primera vez en Argentina hace más de 10 años a partir de un brote de mastitis en 